\title{
Resim İş Eğitiminde Resim Akımlarını Anlama ve Anlamlandırma Üzerine Bir Öğretim Yaklaşım Önerisi: Bütüncül Öğretim Yaklaşımı
}

\section{A Proposal of Multifaceted Learning Approach on the Understanding and Interpreting Art Movements in the Visual Arts Education}

\begin{tabular}{l}
\hline Makale Hakkında \\
Gönderim Tarihi:01.07.2 \\
Kabul Tarihi:07.10.202 \\
Yayın Tarihi:01.11.202 \\
Anahtar Kelimeler \\
Resim sanat1, \\
sanat akımları, \\
empresyonizm, \\
Monet, \\
Renoir.
\end{tabular}

Renoir.

\section{Kani ÜLGER ${ }^{1}$}

\section{$\ddot{\text { Ozet }}$}

Objeyi tuvale aktarmada teknik ve düşünsel temelde şekillenen sanatsal karakteristik özelliklerdeki sinıflamayı resim sanatında "akım" olarak adlandırıyoruz. Resim akımlarında sözü edilen sinıflamada bilimsel-teknolojik gelişmelerle tarihsel dönem ve elbette ki üslubuyla sanatçı çok önemli rol oynamaktadır. Bu bağlamda sanat eseri, yaşanan çağın nesnel yansımalarıyla birlikte ressamın öznelliğinde anlamını bulan görsel bir bileşkedir. Dolayısıla, ögrencilerin resim akımlarını anlama ve anlamlandırmada, sanat eğitiminde çok yönlü bir bakış açısına ihtiyaç olduğu söylenebilir. Buna karşın, ilgili alan ĕgitim programlarında ders içeriği, sunum planı ve ögretim yöntemi açısından dağınık bir yapı sergilendiği gözlemlenmektedir. Bu durum, karmaşık ve çok yönlü içeriğe sahip olan resim akımlarını ögrenci açısından, anlama ve anlamlandırmada bir sorun oluşturduğu ileri sürülebilir. Bu araştırmanın amacı; öğrencilerin resim akımlarını anlama ve anlamlandırmaları için, sanat eğitimi alanına bütüncül bir öğretim yaklaşımı önerisi getirmektir. Buna göre, araşstırmanın yanıtını aradığ soru: "Öğrenci için resim akımlarını anlama ve anlamlandırmada bütüncül bir ögretim yaklaşımı geliştirilebilir mi??" biçiminde düzenlenmiştir. Tarama yönteminde yapılan araştırmanın sonucu; kronolojik bağlamda sanat eserinin yapıldı ̆̆ dönem özellikleri, bilimsel-teknolojik gelişmelerle sosyal-kültürel yapı ve sanatçı odağında, resim akımlarını çok yönlü bir bakış açısıyla ele alacak, bütüncül bir öğretim yaklaşımın geliştirilebileceği yönündedir. Bu sonuç doğrultusunda, ögrenciler için resim akımlarını anlamak ve anlamlandırmalarına yardımcı olabilecek bütüncül bir öğretim yaklaşım önerisi geliştirilmiştir.

\section{Abstract}

The art movement in the painting defines as a characteristic to reflect the object to the

Key Word

\section{Painting art,} art movements, impressionism, Monet, Renoir. canvas through the technical and intellectual basis of the artist with features of an era. The artist's style also plays a very important role in the art movements with together the scientific-technological developments and the socio-cultural structure. Therefore, artwork is a visual composition that finds its meaning in the subjectivity of the artist with the reflections of the era. For this reason, there is a need for a multifaceted perspective in art education in terms of understanding and interpreting the art movements for students. On the other hand, the visual arts education programs display a disordered structure in course content, presentation and learning method, which impedes students' understanding and interpreting of complex and multifaceted the art movements. The purpose of this research is to suggest a multifaceted-holistic learning approach to the art education in understanding and interpreting the art movements objectively for students. Accordingly, the research question is determined as follows: "Could a multifaceted-holistic learning approach be developed in understanding and interpreting the art movements for students?" This study used document analysis technique as based on the literature review. Consequently, this study concluded that a multifaceted-holistic learning approach for the art movements is possible to develop objectively in considering the socio-cultural structure in the related era and technological developments including with the artist who made the artwork. Therefore, this study suggested a multifaceted learning approach in order to understand and interpret of the student's art movements.

Atıf için:

For Citation
Ülger, K. (2021). Resim İş eğitiminde resim akımlarını anlama ve anlamlandırma üzerine bir öğretim yaklaşım önerisi: Bütüncül öğretim yaklaşımı. Muğla Sitkı Koçman Üniversitesi Eğitim Fakültesi Dergisi [MSKU Journal of Education], 8(2), 422-435. DOI: $10.21666 /$ muefd.761797

\footnotetext{
${ }^{1}$ Sivas Cumhuriyet Üniversitesi Eğitim Fakültesi - kulger@gmail.com- ORCİD No:0000-0001-7435-175X
} 
Resim sanatında teknik ve düşünsel temelde değişimlerin tuvale karakteristik biçimde yansıması, "resim sanat akımı" olarak adlandırılabilir. Bu tür akım adlarına eklenen "izm" sonekiyle türetilen isimler (Empresyonizm, Sürrealizm gibi), resim akımlarının diğer bir karakteristik özelliği olarak ortaya çıkmaktadır. Bu sanat akımları incelendiğinde, resimde kullanılan boyama tekniği eserin üretildiği dönemi yansıtan önemli bir belirteç olabilmektedir. Benzer biçimde, kompozisyon kurgusu veya yapıttaki figürsel yaklaşım da bize resmin dönemi hakkında önemli ipuçları verebilmektedir. Resmin tekniğinden başka, akımlarda dönemin başat düşünsel yönünü de dikkate almak gerekir. Bunun yanında, sanatçının kişiliği, resim üslubu hakkında bilgiler, dönemin bilim ve toplum açısından önemli gelişmeler de göz önünde bulundurulmalıdır. Dolayısıyla, resim akımlarını ortaya çıktıkları dönem, sanatçı, sosyal-kültürel, ekonomik yapı ve bilimsel-teknolojik gelişmelerden bağımsız olarak ele alınamayacağını söyleyebiliriz. Ayrıca, sanat eserindeki konu ve içerik de önemlidir. Buna ek olarak, resim akımlarının tarihsel açısından kronolojik biçimde ele alınması, resim sanatını kavramada yardımcı olacak diğer önemli bir unsur olarak değerlendirebiliriz. Sanatçı yaptığı eser ile bağlamdan, yaşadığı tarihsel dönemden ve buna ilişkin yukarıda sıralanan diğer unsurlardan bağımsız değerlendirilemez. Bu nedenle, sanatçının ürettiği eser; nesnel olarak yaşanan çağın yansımaları ile öznel açıdan sanatçının bireyselliğinde anlamını bulan görsel bir bileşkedir, diyebiliriz. $\mathrm{Bu}$ perspektiften konuya yaklaştığımızda, resim akımlarını anlama ve anlamlandırmada çok yönlü bir bakış açısına ihtiyaç olduğu söylenebilir. Bu durum özellikle, ortaokul, lise ve yükseköğretim düzeyinde, resim iş eğitiminde öğrencilerin resim sanatını anlama ve anlamlandırmaları açısından önemlidir. Bu bağlamda, yükseköğretim düzeyinde öğretmen adayı öğrencilerin resim akımları konusundaki kazanımları, aynı zamanda öğretmenlik yapacakları orta dereceli okul öğrencilerin sanatı anlama, anlamlandırma ve kendi yaşamlarına içselleştirmeleri yönünde önemli bir katkı yapacağı kuşkusuzdur. $\mathrm{Bu}$ yolla, öğretim programında atölye-uygulamaya dayalı derslerin yanında, teorik bilgiye dayalı yapı desteklenerek, yarının bireylerini oluşturacak öğrencilerin toplumda Sanat'a dair anlamı ve anlamlandırmayı "olumlu" yönde geliştirecekleri söylenebilir. Bu noktada eğitimcilere düşen görev; öğrencilere sanata dair yüzeysel değil, anlam derinliğine sahip bir bakış açısı kazandırmak için, resim akımları konusunda öğrencilere anlama ve anlamlandırmaya yönelik öğretim yaklaşımları geliştirmektir. Öğrencinin resim akımlarını anlama ve anlamlandırma açısından üstte sıralanan tüm unsurların öğretim sürecine dâhil olduğu, bütüncül bir öğretim yaklaşımının geliştirilmesi mümkün olabilir. Bu yolla, öğrencilerin kazanım olarak resim sanatını ve akımlarını daha yetkin biçimde içselleştirmesi beklenebilir. Buna karşın, ilgili alan eğitimi Resim İş Eğitimi ve Görsel Sanatlar Ders öğretim programlarında ele alınan resim akımları konusunun, dersin bir ünite başlığı ya da alt bir başlık konumunda, bütüncül bir yapı sergilediğini ileri sürmek zordur. Bu yapıyla ele alınan resim akımları konusu, ders içerikleri bakımından, ilgili akımın başat sanatçısıyla ya da eseriyle ilişkilendirilen bir çatı olarak karşımıza çıkmaktadır. Oysa resim akımları konusunun öğrencinin anlamlandırması bakımından, geniş bir bakış açısına ihtiyacı vardır, çünkü resim akımları ve buna bağlı sanat eseri oldukça karmaşık ve çok yönlü bir yapı içerir. Bu haliyle konunun ilgili ders kazanımının, anlamlandırma yönünden öğrenciyi yeterince desteklediğini söylemek zordur. Öğrencinin belleğinde anlamlı bir izlek oluşturmak için resim akımlarının daha geniş ve kapsayıcı bir bakış açısıyla, bütüncül ele alınması gerekir. Bu nedenle, resim iş eğitimi ve görsel sanatlar eğitiminde sanat akımları konusunun öğretilmesi ve öğrenilmesinde, kronolojik bağlamda çok yönlü bir bakış açısıyla geliştirilen, bütüncül bir öğretim yaklaşımına ihtiyaç olduğu ileri sürülebilir. Bu bağlamda, Ormond $(2011,567)$ sanat eserlerinin konu, içerik ve üslup gibi unsurların birlikte ele alınarak değerlendirilmesiyle anlamlı hale gelebileceğini belirtmektedir. Resim akımlarını nesnel ve özgün bir biçimde anlayıp, anlamlandırabilmek için, başta akımın sanatçıları olmak üzere, dönem koşullarının çok iyi bilinmesi gerekir. Dolayısıyla, eserin konu-içerik bağlamında ele alınmasının yanı sıra, yapıldığı dönemin sosyal-kültürel yapısı, bilimsel ve teknolojik gelişmeleri de göz önünde bulundurulmalıdır. Böylece resim akımları; resmin konusu, tekniği ve sanatçının üslubunun yanında, dönemin sosyal-kültürel yapısı ile bilimsel ve teknolojik gelişmelerin bileşkesinde temellenen, resim sanatındaki karakteristik görsel yansımalarla biçimlenen sanat hareketleri olarak daha bütüncül incelenebilir.

Phillips $(2016,6)$, resim akımlarının türetilmesini daha çok 19. yüzyıl sonu ve 20. yüzyıl başında olduğuna dikkat çekerek, ilgili akımları sanatçı gruplarının kendilerini tanımlamak için kullandıklarını belirtmektedir. Ayrıca, sanatçıların yapıtlarını diğerlerinden ayıran şeyin ne olduğunu açıklamasına ilişkin kullandıkları manifestoları da sözü edilen dönem aralığında daha sık görüldüğünü 
bildirmektedir. Resim akımlarının manifesto biçimde ortaya çıktığı 19. yüzyıl sonu ve 20. yüzyıl başı olarak nitelenen dönem özellikle, sosyal-kültürel, ekonomik yapı ile bilimsel ve teknolojik gelişmelerin hızlandığı tarihsel zaman dilimi olması bakımında anlamlıdır. Bu durum aynı zamanda, resim akımlarını anlama ve anlamlandırmada yukarıdaki satırlarda sözü edilen unsurları eklemenin ne denli gerekli olduğunu da açıklar nitelikte olduğu söylenebilir. Dolayısıyla, ressamların kendilerini önceki ustalardan ve çağdaşlarından ayıran özellikleri anlatan akım manifestolarından çok daha fazla şeye ihtiyacımız olduğu açıktır. Buna göre, öğrenci belleğinde resim akımlarını anlama ve anlamlandırmada, konuyu geniş bir perspektifte ele alan, bütüncül bir öğretim yaklaşımının gerekli olduğu söylenebilir.

$\mathrm{Bu}$ araştırmanın amacı; öğrencilerin resim akımlarını anlama ve anlamlandırmalarına yardımcı olacak, sanat eğitimi alanına özgü, bütüncül bir öğretim yaklaşımı önerisi geliştirmektir. Bu amaç doğrultusunda araştırmanın yanıtını aradığı soru şu şekilde belirlenmiştir: "Öğrenci için resim akımlarını anlama ve anlamlandırmada bütüncül bir öğretim yaklaşımı geliştirilebilir mi?"

\section{Yöntem}

$\mathrm{Bu}$ araştırma doküman analizi yönteminde tarama tekniğindedir. Araştırma problemi doğrultusunda yapılan literatür taraması (McCombes, 2020), seçilen konu alanındaki mevcut literatürün araştırılması (What is a literature review?, 2020) ve doküman analiziyle değerlendirilmesi biçimindedir. Doküman Analizinde araştırmacı, dokümanların araştırma problemi ve amacına uygunluğunu belirleyip, belgeleri inceler ve değerlendirir. $\mathrm{Bu}$ değerlendirmeden sonra elde edilen verileri araştırmacı yorumlayarak, ilgili konu hakkında bilgi geliştirir (Kıral, 2020).

\section{Verilerin Toplanması ve Analizi}

$\mathrm{Bu}$ araştırmadaki veriler literatür taraması yoluyla toplanmıştır. Literatür taraması, araştırma konusu hakkında alanda mevcut bilgileri tespit ederek, bunların tüm yönleriyle ortaya konulması sürecidir (Literature Review, 2020). Bu yolla ulaşılan veriler, elden geçirilerek tasnifi yapılır (Karadağ, t.y.) ve araştırma sorusunun kapsamındaki dokümanlar (Koçak ve Arun, 2006, s.24) içerik analizi ile incelenebilir (Íçerik Analizi.., 2017). "İçerik analizi” aşaması dokümanın analizinde kullanılan bir çözümleme yöntemi olarak öne çıkmaktadır (Kıral, 2020).

\section{Bulgular}

Milli Eğitim Bakanlığı (MEB) Güzel Sanatlar Lisesi öğretim programında "Çağdaş Dünya Sanat1 Tarihi" dersinde alt başlık olarak yer alan; resim akımları konusu, dersin amaçları açısından iki maddede ifade edilmiştir. Bunlar; "Sanat akımlarını, eserlerini ve sanatçıları tanıma" ile "Sanat eserini ve sanatçı1 anlama"dır (MEB Güzel Sanatlar Lisesi öğr.., 2016, s.4). Bu bağlamda "anlama", "anlamlandırma"nın ilk basamağı olduğu söylenebilir. Ancak ilgili amaçlar yalnızca konunun bilişsel yanı olan "anlama" yı içermekte, duyuşsal yönün (anlamlandırma) yer almadığı görülmektedir. Dersin kazanımları açısından da benzer bir durum söz konusudur. Oysa Bloom Taksonomisi (BT) bilişsel, duyuşsal ve psikomotor olarak öğretim hedeflerini üç öğrenme alanına göre düzenleyip, değerlendirmektedir. İlgilerin, değerlerin ve tutumların değişimi, yaşama uyum sağlanması ve değer olarak kabullenme durumunun geliştirilmesi duyuşsal alan kapsamındadır (Beyreli ve Sönmez, 2017, s.215). BT’nin öğretim programlarında sıklıkla öğrenme amaçlarını yapılandırmak için kullanıldığı (Bloom's taxonomy, t.y.) dikkate alınırsa, ilgili dersin öğretim planlanmasında "anlamlandırma" unsurunun yeterince yer almadığı ileri sürülebilir. İlgili "Çağdaş Dünya Sanatı Tarihi” dersinin program açısından sanat akımları konusunun öğretiminde; sanatçıların öz geçmişlerine yer vererek, akımın önemli eserlerinin öğrenciye tanıtılması salık verilmektedir. Bununla birlikte, Modernizm dönemine ilişkin modernizmi doğuran nedenlerin (sanayi devrimi vb.) sanata yansımalarına yer verilmesi önerilirken (MEB Güzel Sanatlar Lisesi öğr.., 2016, s.12), diğer akımlar için bu tür dönemsel içerikli bir yaklaşım gözlemlenmemektedir. Bu yolla, dersin öğretimi sadece sanatçının özgeçmişi ve sanat eseri çerçevesinde biçimlenmekte, dönem özellikli içerik ise muğlak görülmektedir. Oysa resim akımları konusunun öğretiminde ilgili tarihsel döneme yer verilmesi, bağlam açısından öğrencinin konuyu anlamlandırmasında önemli bir unsurdur. Yapılan araştırmalar 
öğrencinin konuyu anlamlandırmasında yaşama dayalı bağlantıların önemli olduğunu göstermiştir (Güneş ve Öner, 2017, s.346-352). Buna göre, ilgili dersin öğrenmenin "duyuşsal” yönünü anlamlandırma açısından yeterince destekleyemediği için, öğrencinin resim akımlarını anlamlandırmasında, bütüncül bir öğretim yaklaşımının geliştirilmesinin gerekli olduğu ileri sürülebilir.

Diğer taraftan, Görsel Sanatlar Dersi (9,10,11 ve 12. Sınıflar) öğretim programında kazanımlar; sanat eleştirisi ve estetik, kültürel miras ve görsel sanatlarda biçimlendirme öğrenme alanlarında bir kapsamı içerdiği görülmektedir (MEB Görsel Sanatlar Dersi.., 2018, s.14). İlgili programda "sanat akımları" yalnızca 11. Sınıfta "Batı resim sanatına genel bakış" alt başlığında yer almakta, öğretim içeriği ise, resim akımlarının çıkış nedenleri, belli özellikleri ve akımın önde gelen temsilcilerin eser örneklerine yer verilmesi biçiminde (MEB Görsel Sanatlar Dersi.., 2018, s.22) şekillenmektedir. Buna göre, görsel sanatlar dersi modern sanat akımları başlığı altında BT kapsamında, öğrencilerin konuyu anlamlandırma açısından duyuşsal boyutu çok güçlü biçimde desteklediği ileri sürülemez.

2018-2019 Öğretim yılından itibaren uygulamaya konulan yükseköğretim düzeyinde Resim İş Eğitimi Öğretmenliği Lisans Programında ise, Alan Eğitimi (AE) olarak, III. Yarıyılda (2. Sinıflar, Güz Dönemi) verilen; "Batı Sanatı Tarihi” dersinin içeriğine bakıldığında, Roma dönemi sanatından, 19. yüzyıla kadar süregelen resim, heykel ve mimari açısından örneklerin karşılaştırmalı olarak incelenmesinin amaçlandığı gözlemlenmektedir (Resim- $\dot{I}_{S ̧}$ Öğretmenliği.., 2018, s.10). Bununla birlikte, programda VI. Yarıyılda (3. Sınıflar, Bahar Dönemi) AE olarak verilen; "Çağdaş Sanat" dersinin içeriğinde sanat akımları konusu, 19. yüzyılın sonundan başlayarak, günümüze değin ele alan bir yapıda, belli başlı sanatçılar ve eserlerin karşılaştırması biçiminde geliştiği görülmektedir (Resim- $\dot{I S S S}_{S}$ Öğretmenliği.., 2018, s.13). İlgili programda yer alan Batı Sanatı Tarihi ve Çağdaş Sanat derslerinin adları farklı olsa da içeriklerinin kronolojik olarak birbirinin devamı olduğu söylenebilir. $\mathrm{Bu}$ programdaki en büyük çelişki ise, "anlamlandırma" açısından bu noktada ortaya çıkmaktadır. Buna göre, ilgili derslerin dilimlenmiş yapısını, konuların farklı sınıflarda birbirini takip etmeyecek biçimde işlenmesiyle, anlamın parçalanması olarak niteleyebiliriz. Dolayısıyla, ilgili program çerçevesinde öğrencinin resim akımlarını anlamlandırmada yükseköğretim düzeyinde de bütüncül bir öğretim yaklaşımı olmadığını ileri sürebiliriz.

Bununla birlikte, ilgili alan yazında yapılan çalışmalar, sanat eğitiminde kapsayıcı yaklaşımların öğrenime olumlu etkileri üzerine bulguları raporlamaktadır. Yarımca (2010, s.99) disiplinler arası bir yaklaşımla yapılan sanat eğitiminin ortaokul öğrencilerinin öğrenmeleri üzerine etkisini araştırmış, söz konusu yaklaşımın geleneksel yönteme göre daha kalıcı olduğu sonucuna ulaşmıştır. Kurtuluş (2001, s. 204-205), sanat eğitiminde işbirlikli öğrenme yaklaşımının öğrencilerin bilişsel, duyuşsal ve devinişsel alanlarda gelişmelerini desteklediğini bulmuş, öğrencilerin farklı yaklaşımlar yoluyla zengin olanaklara kavuşturulmasının önemini vurgulamıştır. Yükseköğretim açısından, Erem (2009) sınıf öğretmenliği öğretmen adaylarına sanat akımları konusunu yaratıcı drama yöntemiyle işlemiş, katılımcı öğrencilerin bu tür bir öğrenme yaklaşımının öğrenmede daha etkili olduğunu ifade ettiklerini bildirmiştir. Gözlükaya Işık $(2014$, s.111) ise, yükseköğretim düzeyinde resim iş eğitimi öğrencilerine aktif öğrenme tekniklerini uygulamış, çalışma sonucunda ilgili yöntemin öğrenme sürecini olumlu yönde desteklediği bulgusuna ulaşmıştır. Deneysel yöntemde yapılan diğer bir çalışmada da "Çağdaş Sanat" dersinde yer alan "Pop Art akımı" konusu Resim iş eğitimi öğrencilerine Çok Alanlı Sanat Eğitimi Yöntemi (ÇASEY) ile işlenmiş, klasik yöntemlere göre öğretmen adaylarının öğrenmelerinde ÇASEY'in daha etkili olduğu bulunmuştur (Güneş, 2015, s. 373-374). İlgili bu araştırmaların tümünde farklı öğretim yöntemlerinin uygulandığ 1 dikkate alınırsa, resim akımları konusunda yeni öğretim yaklaşımların denenmesinin ne denli bir öneme sahip olduğu konusu daha iyi anlaşılabilir. Dolayısıyla, resim akımları konusunun öğretiminde, öğrencinin bilişsel öğrenme alanına dayalı içeriğin yanında, duyuşsal öğrenme alanının da desteklendiği bütüncül bir öğretim yaklaşımına ihtiyaç olduğu söylenebilir. 


\section{Tartışma, Sonuç ve Öneriler}

$\mathrm{Bu}$ çalışmanın yanıtını aradığı soru: "Resim akımlarını anlama ve anlamlandırmada bütüncül bir ögretim yaklaşımı geliştirilebilir mi" biçiminde düzenlenmiştir. San (2004, s.38), temel sanat kuramları olarak; Yansıtmacı, Anlatımcı, Duygusal Etki ve Biçimci Sanat kuramlarının, "sanatçı", "sanat ürünü", "sanat tüketicisi" ve "çevre" biçiminde sıralanan dört ögeden birine yöneldiğini belirtmektedir (Şekil 1). Kimi sanat kuramları, bu ögelerden birine diğerlerine göre daha çok odaklanırken kimi sanat kuramları da bir başka ögeyi diğerine göre daha fazla önemsemektedir. Buna karşın, sanat kuramlarının odaklandığı ögelerin bütüncül bir yaklaşımla, tümdengelim yöntemiyle ele alındığında, sanat akımlarına ve dolayısıyla sanat eserine daha geniş bir perspektiften bakılabilmesi mümkündür. Bu bağlamda sanat eseri konu, içerik ve üslup gibi unsurların yanı sıra, resim akımına ilişkin dönem koşulları ve bilimsel - teknolojik gelişmeler de dikkate alınarak dersin işlenmesi, öğrenci açısından konuyu anlama ve anlamlandırmada daha yetkin bir öğretim yaklaşımına işaret edebilir. Dolayısıyla, resim akımlarını öğretme sürecinde, Şekil 1'de görülen sanatın tüm unsurlarını içeren bütüncül bir öğretim yaklaşımının tasarlanması mümkün olabilir (bkz. Diyagram 1).

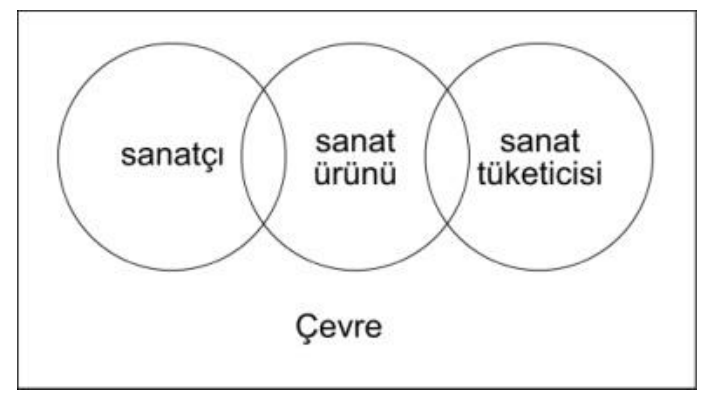

Şekil 1. Temel Sanat Kuramlarının Odaklandığı̈ Ögeler

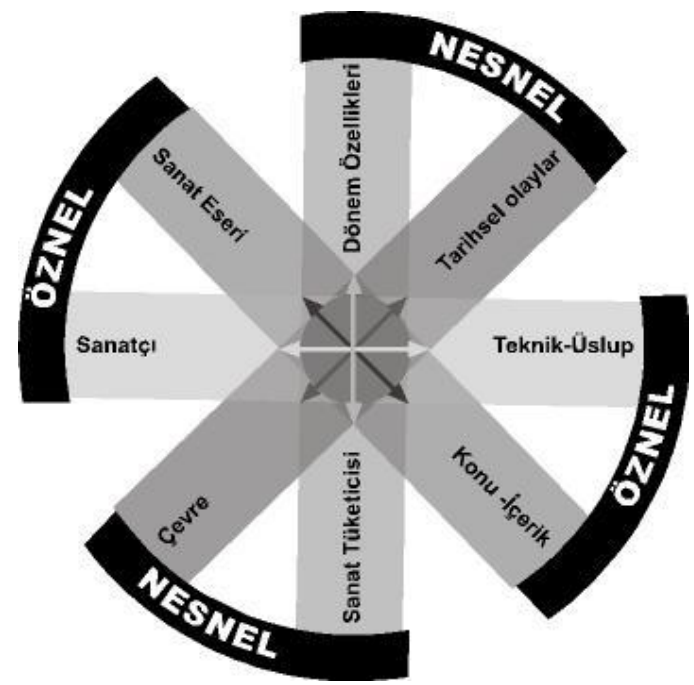

Diyagram 1. Sanat Eğitiminde Bütüncül Öğretim Çarkı

Sekil 1'deki çevre ve sanat tüketicisi unsurları, Diyagram 1'de verildiği biçimde, sanatçının eserini oluşturduğu dönem özellikleri kapsamında, dönemin sanat anlayışı, sosyal-kültürel, ekonomik yapısı ve bilimsel-teknolojik gelişmeler göz önünde tutularak karşılanabilir. Diğer yandan, Sekil 1'deki sanatçı ve sanat ürünü ögeleri, Diyagram 1'de verildiği biçimde, sanatçının kişsiliği, tekniği (tarzüslup), sanat eseri, konu ve içerik bağlamında değerlendirilebilir. Dolayısıyla, bütüncül bir öğretim yaklaşımında tümdengelim yöntemiyle, resim akımlarını sanatın tüm unsurlarını içerecek biçimde Diyagram 1'de sunulduğu haliyle göz önünde bulundurarak, alttaki gibi maddeleyip, sıralayabiliriz:

1- Dönem özellikleri (sosyal-kültürel, ekonomik yapı, bilimsel-teknolojik gelişmeler ve sanat)

2- Sanatçının kişiliği

3- Sanatçının eserinde konu ve içerik

4- Sanatçının tekniği (tarz-üslup) 
Resim akımlarını tarihsel kronolojiye uygun biçimde, dönem özellikleri göz önünde bulundurarak, sanatçıların kişiliğiyle harmanlamış biçimde, sanat eserleri içeriğinde bütüncül bir yaklaşımla incelenebilir. Yukarıda ortaya konulan başlıca maddeler kapsamında, süreçteki tüm unsurlar ve rolleri, öğrenci açısından daha açık biçimde kavranabilir. Bu tür bir yaklaşımla, resim akımlarını öğrenme sürecinde öğrenciye, anlamak ve anlamlandırma açısından daha bütüncül bir öğretim sunulabilir. Anlamlandırmak sözcüğü, Güncel Türkçe Sözlükte birinci mana olarak; "Anlamını açıklamak”, ikinci manası ise, "Anlam vermek, anlam kazandırmak" biçimindedir (https://sozluk.gov.tr/). Anlam vermek yine aynı sözlükte "kendince bir yargıya varmak, yorumlamak" olarak tanımlanmaktadır. Buna göre, ilgili öğretim programlarında öğrencinin resim akımlarını yorumlayarak kendince bir yargıya varması için, ders içeriğinin zenginleştirilmesinin önemli olduğu söylenebilir. Böylece öğrencinin resim akımlarını anlamlandırmasında, eserdeki konu, içerik ve üslup gibi unsurların yanı sıra, kronolojik olarak akımın dönem koşulları ve bilimsel - teknolojik gelişmeler de dikkate alınarak, dersin bütüncül bir yolla işlenmesi mümkün olabilir. Bu bağlamda, Yükseköğretim düzeyinde Resim İş Eğitimi programında Batı Sanatı Tarihi ve Çağdaş Sanat adlı (AE) derslerin kronolojik açıdan parçalı yapısı, "Resim Akımları-I" ve "Resim Akımları-II" adlandırması altında, birbiri ardına (Güz ve Bahar) iki dönemli bir ders olarak programa eklenerek, ilgili dersin bütüncül bir yapıya kavuşturulması önerilir. İlgili derslerin programa eklemlenmesi bu yolla mümkün olmaz ise, ilgili bölüm ya da anabilim dalının önerisiyle, "Resim Akımları" programa seçmeli dersler (Alan Eğitimi Seçmeli) kategorisinden eklemlenmesi ilgili kurullarda değerlendirilebilir. Dolayısıyla, söz konusu dersin içeriği, anlam parçalanması olmadan, yeniden düzenlenerek programda yer alması mümkün olabilir. Sonuç olarak, bu çalışmanın ulaştığı bulgular ışığında, bir çerçeve içinde izlek oluşturma adına, Resim iş eğitimi ve Görsel sanatlar öğretiminde resim akımları konusunun bütüncül bir öğretimi yaklaşımı ile işlenmesine ilişkin özgün bir öneri geliştirilmiş ve alttaki satırlarda sunulmuştur.

\section{Bütüncül Öğretim Yaklaşımı Önerisi \\ Ders Planı}

Ders: Resim Akımları

Konu: Empresyonizm (İzlenimcilik)

Süre: 2 Saat

Yöntem: Bütüncül Öğretim Yaklaşımı

Amaç: Tüm yönleriyle Empresyonizm akımını anlama ve anlamlandırma.

Kazanım: Empresyonizm akımı hakkında bilişsel ve duyuşsal yönden bilgi ve tutum sahibi olma.

Materyal: Diyagram 1

Ders İşleniş (1. Aşama): Empresyonizm akımının ortaya çıktığı tarihsel dönem çeşitli yönleriyle ele alınır: Dönemin sosyal-kültürel, ekonomik yapısı nasıldır? İlgili dönemde öne çıkan önemli bilimsel ve teknolojik gelişmeler nelerdir? Dönemin sanat anlayışı nedir? türünden sorulara yanıt aranarak, Empresyonizm akımının tarihsel dönem özelliği incelenir.

A- Dönem özellikleri (sosyal-kültürel, ekonomik yapı, bilimsel-teknolojik gelişmeler ve sanat):

Ders İşleniş (2. Aşama): Empresyonizm Akımının sanatçıları, akımda yer aldıkları hiyerarşiye uygun olarak kişisel özellikleri ile ilgili eserdeki konu-içerik ve sanatçının üslubu incelenir.

B- Sanatçının kişiliği

C- Sanatçının eserinde konu ve içerik

D- Sanatçının tekniği (tarz-üslup)

Ders Giriş

İşleniş (1. Aşama): Empresyonizm akımının ortaya çıktı̆̆ı tarihsel dönem çeşitli yönleriyle ele alınır. Dönemin sanat anlayışı nedir? - Dönemin sosyal-kültürel, ekonomik yapısı nasıldır? - İlgili dönemde öne çıkan önemli bilimsel ve teknolojik gelişme var mıdır? Sorularına yanıt aranarak, Empresyonizm akımının çıktığı dönem incelenir. Dersin bu aşamasında materyal olarak Diyagram 1 kullanılır. İlgili diyagramda yer alan her bir şeridin kendi içinde karşılığı ve bu şeritlerin "öznel" ve "nesnel" perspektiften nitelikleri ile tüm çark içindeki bütünselliğe dikkat çekilir. Ders bu aşamada konuya giriş özelliği taşıdığ 1 için, materyal olarak kullanılan ilgili diyagramın hangi şeridinden derse başlanacağ öğrenci tercihine bırakılır. Diyagram 1'de seçilen herhangi bir şeridin çark içindeki ilişkilerine dikkat çekilerek dönem özelliğine atıf yapılır ki, bu yolla öğrenci merkezli olarak dersin işlenmesine önemli bir başlangıç oluşturabilir.

\section{A- Dönem özellikleri}


XIX. Yüzyıl Avrupa ekseninde dönemin sosyal-kültürel, ekonomik yapı, bilimsel-teknolojik gelişmeler ve sanat.

\section{Sosyal-kültü̈rel, ekonomik yapt}

Fransız Devrimiyle anlam kazanan, “özgürlük, eşitlik, kardeşlik" kavramları Avrupa kıtasını iki yüzyıl boyunca etkilemiş, modernlik bu çizgi üzerine kurulmuştur (Artun, 2010, s. 16). Günümüze dek ulaşan modernite, Aydınlanma Çağının (1687-1789) bir nevi devamı olarak, Rene Descartes ve Immanuel Kant gibi filozofların rasyonalizm anlayışında temellenen özgürlük ve birey üzerinden demokrasi, kapitalizm, sanayileşme, bilim ve şehirleşmenin genel adı olarak karşılığını bulmuştur (Barrett, 2012, 47-49). 19. yüzyıl Avrupa'sında geçmişin (18. Yüzyıl) idealist insancılllı̆̆ yerini toplumsal ve siyasal reform taleplerine bırakmış, artan kentsel ve kırsal yoksulluk, sanayinin yükselişi, orta sınıfın refahı, gecekondularda süregiden yaşam Marx ve Pierre Proudhon gibi kuramcılara düşün kaynağı olmuştur (Hollingswort, 2009, s. 417-418).

\section{Bilimsel-teknolojik gelişmeler}

19. yüzyılın ilk yarısında, buhar makinesi teknolojisinin geliştirilmesiyle, üretimde, ulaşımda ve sosyal yaşamda önemli değişiklikler olmuştur. Bu teknoloji sayesinde seri üretim artmış, geniş kitleler üretimde yer alış ve bu yolla yeni bir çalışan sınıf meydana gelmiştir. 19. yüzyılın ikinci yarısında ise, elektrik teknolojisiyle üretim, aydınlatma, ulaşım ve iletişim (telgraf ve telefon) alanlarında büyük gelişmeler olmuş, halkın yaşam standartları ve refah düzeyi yükselmiş, bu gelişmelere bağlı olarak, şehirler büyümüş, nüfusları artmış ve bu durum 19. yüzyılda modern ulusların doğuşunda önemli bir rol oynamıştır (Bahadır, 2017). Diğer taraftan, fotoğraf makinesi Fransız fizikçi Joseph Niepce tarafından 1826 yılında icat edilmiş, 1839'da geliştirilerek, fotoğraf makinesinin daha net fotoğraflar çekilebilmesi sağlanmıştır. Fotoğraf makinesinin icadı 19. Yüzyıl Avrupa'sında sanatsal alanda çok büyük gelişmelere neden olmuştur (Güzel, 2012).

\section{Sanat}

Bu dönemde Charles Baudelarie, Emile Zola ve Charles Dickens gibi yazarlar için yeni bir konu alanı açılmış, Baudelarie'in sanatçıları "modern yaşamın kahramanlığına" teşvik eden çağrısı ile geçmişin üslup, konu ve kurallarını reddeden ressamların sayısının artmasıyla bir tür karşılık bulmuştur (Hollingswort, 2009, s. 417-418). 19. Yüzyılda Fransa'da ortaya çıkan Realizm akımı ressamlarının başında gelen Courbet, burjuva ve köylülerin yaşamını betimlediği resimlerle çağdaşı olan Romantik akımın sanatçılarından farklı olarak, resimlerinde görkemli sahneleri yansıtmaktan özellikle kaçınmıştır (Hollingswort, 2009, s.418-419). Buna karşın, Realizm akımının son döneminde (yaklaşık 1860'lar) Paris'te, Eduard Manet, Claude Monet, Pierre Auguste Renoir, Camille Pissaro, Edgar Degas ve Paul Cezanne başta olmak üzere ressamlar, tarihsel ve düşsel konuları resmetmeyi bırakmış, modern yaşamı objektif bir gözle aktarmayı seçmişlerdir. Böylece, resmedilen sahnenin oluşturduğu kısa süreli izlenimi yakalayarak, tuvale aktarmaya çalışan bu ressamlar, Monet ve Renoir tarafindan şekillendirilen, Batı sanat tarihinde "Empresyonizm" olarak bilinen üslubun oluşmasına öncülük etmişlerdir (Hollingswort, 2009, s.421-426; Newall, 2008, s.9). Böylece, Baudelarie'in sanatç1ları "modern yaşamın kahramanlığına" teşvik eden çağrısı resim sanatı açısından karşılığını bulmuştur. Diğer yandan, fotoğraf makinesinin icadıyla resmin biricikliği açısından anlamı değişmiştir. Sonuçta, yağlıboya resim geleneğinde çok anlamlılık meydana gelmiş böylece, resimde kendine has bir görme biçimi oluşmuştur (Berger, 2005, s.19-109). Bu dönemde ortaya çıkan Empresyonizm akımı belirli bir kurama bağlı olmamakla birlikte, nesnelerin nasıl görünmesi gerektiği değil de göründüğü gibi resmetmeye çalışan bir yap1 üzerinde temellenmiştir (Newall, 2008, s. 6). Bu durum, yağlıboya resimdeki geleneksel görme biçimini, Empresyonizm resim akımıyla önemli bir değişime girmesine neden olmuştur (Berger, 2005, s.84). Fotoğraf makinesiyle rastlantısal görünümler keşfedilse de dönemin ressamları fotoğrafın giremeyeceği alanları araştırıp resmedince, modern sanatın bugünkü geldiği yere getiren gelişme meydana gelmiştir (Gombrich, 2004, 525).

İşleniş (2. Aşama): Dersin bu aşamasında Empresyonizm akımının sanatçıları, ressamları sıralanır ve her bir ressam, akımda yer aldıkları hiyerarşiyle ele alınır: İlgili sanatçının kişiliği, eserdeki konu içerik ve sanatçının üslubu incelenir.

B- Sanatçının kişiliği

C- Sanatçının eserinde konu ve içerik

D- Sanatçının tekniği (tarz-üslup)

B- Sanatçının kişiliği (Claude Monet) 
Claude Monet, 14 Kasım 1840'da Paris'te dünyaya geldi. Lise öğreniminden sonra, 1859'da Paris'e resim öğrenimi yapmaya gitti (Claude Monet Hayatı, t.y.). Paris'te Édouard Manet Pierre-Auguste Renoir, Frederic Bazille ve Alfred Sisley ile tanıştı. Monet'nin üniversitedeki geleneksel resim anlayışı nedeniyle hayal kırıklığına uğradığı aktarılmaktadır (Claude Monet, 2020). 1873 sonlarında Monet, Renoir, Cézanne, Sisley ve Pissarro ile bir sergi açmaya karar verir. Monet'nin, 1872'de Le Havre'da resmettiği "İzlenim, Gündoğumu" adlı resmi sergilenenler arasındadır. Eleştirmen Louis Leroy, "İzlenim, Gündoğumu" adlı Monet'nin resmini tüm grubun üslubunu adlandırmada kullanır (Claude M., 2020). Ancak, Leroy "izlenimcilik" (empresyonizm) adlandırmasını, bu üslubu hafife almak amacıyla kullanmıştır (Pişkin, 2018). Monet'nin kişilik olarak ani parlamalar yaşadığı, bazen yaptığı işten hayal kırıklığına uğrayarak, yaptığı resimleri yok etmeye kadar işi götürdüğü bilinmektedir. Monet'nin ayrıca, depresyon ve kendinden şüphe nöbetleri yaşadığı da bilinmektedir (Claude Monet Biography, 2019).

\section{C- Sanatçının eserinde konu ve içerik (Claude Monet)}

"Empresyonistler" (İzlenimciler) ad1, Claude Monet'nin "Impression: soleillevant" adındaki resminden esinlenerek verilmiş bir ad (Newall, 2008, 9) olduğunu tekrar hatırlatarak derse devam edebiliriz.

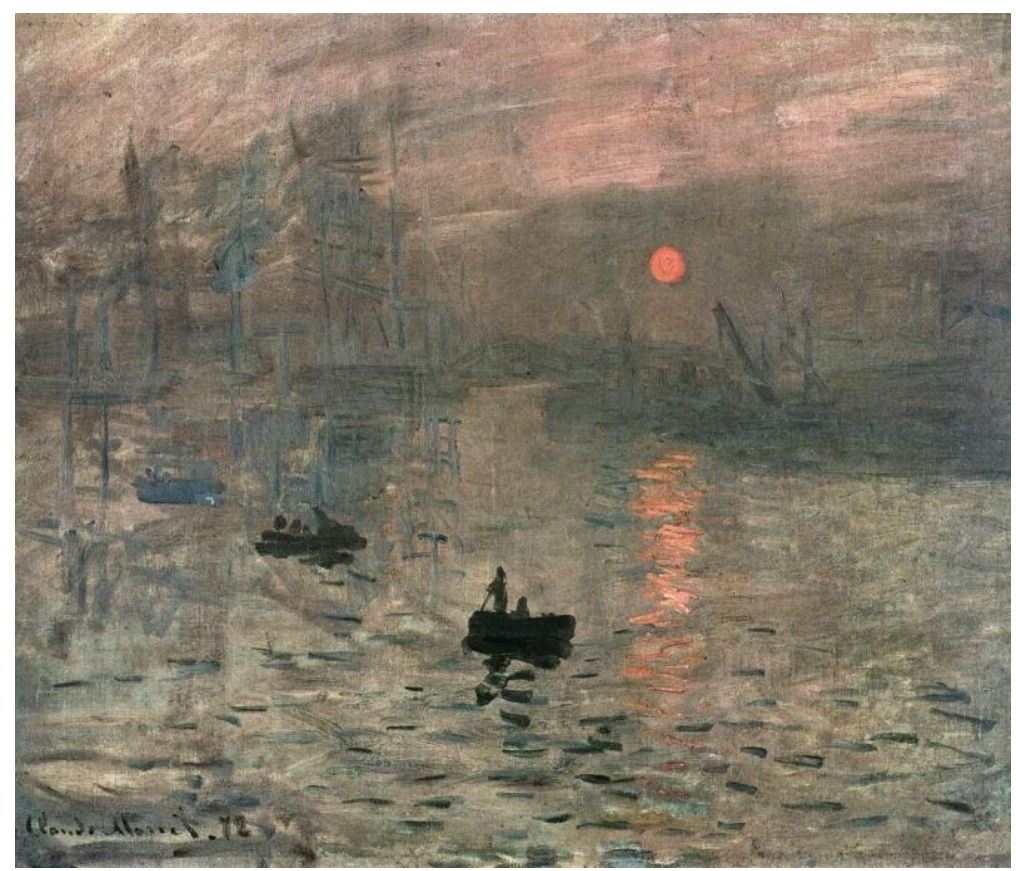

Resim-1: Claude Monet, “İzlenim” / Impression, Sunrise. (1873). Tuval üzerine yağlıboya, 48 x $63 \mathrm{~cm}$. Musée Marmottan Monet, Paris.

İzlenim ya da Gün Doğumu adlı resim (Resim 1) Normandiya'da sisli bir havada La Havre limanının üzerine doğan güneşin, Monet'nin firçalarıyla yakaladığı bu kısacık anın, biçim tarafında yenilikçi bir anlayışla tuvale aktarılmasıydı. Eser bu haliyle, çabuk geçen anın etkisini, çağdaş bir endüstriyel konu çerçevesinde sahneleyip yakalamasıyla kendi zamanı için oldukça yenilikçidir (Newall, 2008, s. 15) ve bu yönüyle Baudelarie'in çağrısına uygun biçimde moderndir. Claude Monet, doğayı konu edinen resimlerin yapıldığ 1 yerde bitirilmesini savunuyordu. Bu tür bir durumda haliyle doğadaki renk ışığa bağlı olarak sürekli değişiyordu. Bundan dolayı, ressamın anı yakalaması için, renkleri tuvale geçirirken hızlı vuruşlarla bir boyama yapması gerekiyordu. Bu yolla ressam eserinde ayrıntıdan çok genelin etkisine dikkat etmesi gerekecekti (Gombrich, 2004, s. 518). Böylece, bu dönem ressamlar tablolarını sağlam bir akademik bilgi yerine doğada geçici bir anın izlenimini yansıtmaya dayandırmış oldular (Gombrich, 2004, s. 519). 1860'lar boyunca Monet'nin stili olan; koyu renk tonları kullanılmadan cesur fırça darbeleri ile vurulması tekniği giderek artan bir ölçüde eskizimsi hale geldi (Newall, 2008, s. 19) ve çağa damgasını vurdu. Kandinsky’ye (2015, s.27) göre, her sanat eseri çağının çocuğudur ve belki de bu nedenle, çoğu zaman duygularımızın kaynağıdır. Dolayısıyla, dönemin başat düşün etkisinin resim sanatına hem konu hem de teknik açıdan bazı değişiklikler 
getirmesi, sanat eserini anlama ve anlamlandırmada dönem özelliklerinin önemini ortaya koyması bakımından kayda değer olduğu söylenebilir.

\section{D- Sanatçının tekniği (tarz-üslup) (Claude Monet)}

"Üslup" (stil) sözcügüü, Romalıların yazma aracı olan stilus sözcüğünden gelmekte, “Akıcı bir kalem”e benzer bir biçimde "yetkin bir üslup" manasına gelmektedir (Gombrich, 1992, s.24). Bir sanat eserinde kişilik ve üslubun yansımaları ne kadar büyük ise, eser de o devrin insanları tarafından o derece tanınır (Kandinsky, 2015, s.70). Leonardo da Vinci, figürlerin katı ve cansız duruşlarını, biçimlerin sert dış hatlarını koyu arka planla kaynaştırma yöntemi olan sfumato tekniğini bularak aşmıştır. Ancak bu boyama tekniği güneş ışığının olduğu açık havada işe yaramıyordu. Bunun üzerine Empresyonistler figürlerin dış hatlarını belirsizleştirmek zorunda kaldılar. Böylece, "tüm detaylar verilmese de yeteri kadar ipucu olduğu sürece izleyicinin resimde olması gereken biçimleri görür" düşüncesi ağırlık kazandı (Gombrich, 2004, 522). Empresyonizm'de resmin boyanmasının bu teknik üzerine şekillendiğini söyleyebiliriz. Bu durum, Empresyonizm akımının öncüsü konumunda olan Monet'nin kişiliğinde anlamını bulan bir karş1lığı olduğu söylenebilir. Monet'nin mizaç olarak, ani parlamalar göstermesi, resimde fiça darbeleri ve nesnenin ayrıntısından daha çok genel görünümünün detaysız konturlarla belirsiz olarak çizilmesiyle ilişkilendirilebilir. Ayrıca resmin yapıldığ 1 yerde bitirilmesi fikri de önemliydi. Bell'in (2009, s.341) belirttiği gibi, Monet, Courbet'in anlık, görünür gerçeklik üzerine sözlerine belki de bu yüzden hayranlık duydu ve resimlerini açık havada resmetti ve bitirdi. Bell'e göre, "İzlenimcilik" fotoğraf bilinci taşıyan 1860'ların ressamları arasında rastlanan bazı sanatsal alışkanlıkların peşine düşmeyi içeriyordu. Bu durum, klasik ressamların tabloyu resmetmeden önce renk tonu ilişkilerini tasarlayarak kullandığ yağlıboya eskizlere benzer bir şey ortaya çıkarıyordu ki tam da bu eskizimsi görünüm, izlenimi yansıtmak uğruna, orijinal tablonun kendisini oluşturuyordu. Böylece resimde, nesneleri oldukları gibi değil, sadece göze, retinaya gelen haliyle yansitan bir araç haline geldiği döneme girilmiş olunuyordu. Bu nedenle Gombrich (2004, s.519), nesnelerin 1şı̆̆ı yansıtma biçimiyle resme yansıtılmalarını, Empresyonist ressamların eserlerini oluştururken, akademik kurallar yerine, bir anın geçici izlenimine dayandırmalarına bağlamıştır.

İşıleniş (2. Aşama): Empresyonizm Akımının sanatçıları, ressamları sıralanır. İlgili ressamların her biri akımda yer aldıkları hiyerarşiyle ele alınır: Sanatçının kişiliği, eserdeki konu - içerik ve sanatçının üslubu incelenir.

B- Sanatçının kişiliği

C- Sanatçının eserinde konu ve içerik

D- Sanatçının tekniği (tarz-üslup)

\section{B- Sanatçının kişiliği (Auguste Renoir)}

Orta halli terzi bir ailenin çocuğu olan Renoir, resme yeteneği fark edilince, ailesi tarafından okuldan alınarak, porselen süslemeciliği atölyesine çırak verilir. Sonraları, bir yelpaze atölyesinde yelpaze resimlemiştir. Bu iş esnasında Renoir ayrıca, klasik ustalara ait 18. Yüzyıl eserlerin taklidi resimlerini büyük bir maharetle yapıyordu. Gençlik yıllarında yaptığı tablolarda orta sınıfın yaşamını yansıtan Renoir'in en büyük düşü resim yapmak olmuştur (Pierre Auguste Renoir, 2020). 1868 yılında sergilenen bir tablosuyla 29 yaşında Paris sanat çevrelerinin kapıları ona açılmış oldu. Paris'te Manet'nin yanı sıra Degas, Bazille, Sisley, Monet, Pissarro ile tanıştı. Güzel sanatlar akademisinde resim dersleri aldı ancak, hiçbir zaman akademik bakış açısıyla arası iyi olmadı (Pierre Auguste Renoir Hayatı, t.y.). 1873'lere dek Empresyonistlere has renkleri kullanma tekniği nedeniyle ünlü Salon, Renoir'in resimlerini sergilemeyi reddetti ancak, sanatçı 1878'de yeniden Salon'a başvurdu. Renoir uzlaşmacı bir kişiliğe sahip olmasına rağmen, İzlenimciliğin 'görsel' yanını doyurucu bulmuyor, daha kalıcı temalara yönelmek istiyordu. Daha sonraki yıllarda İzlenimcilerden uzaklaşmaya başlamıştır (Pierre Auguste Renoir Kimdir?, t.y.). Pierre-Auguste Renoir (1841-1919) romatoid artrit hastasıydı ve 60 yaş civarı hastalığı tehlikeli hale gelmişti. Bu hastalığa rağmen o resim yapmaya devam etti ve çalışmalarının kalitesinden hiç ödün vermedi (da Mota, Neubarth, Diniz, de Carvalho ve Dos Santos Neto, 2012). 


\section{C- Sanatçının eserinde konu ve içerik (Auguste Renoir)}

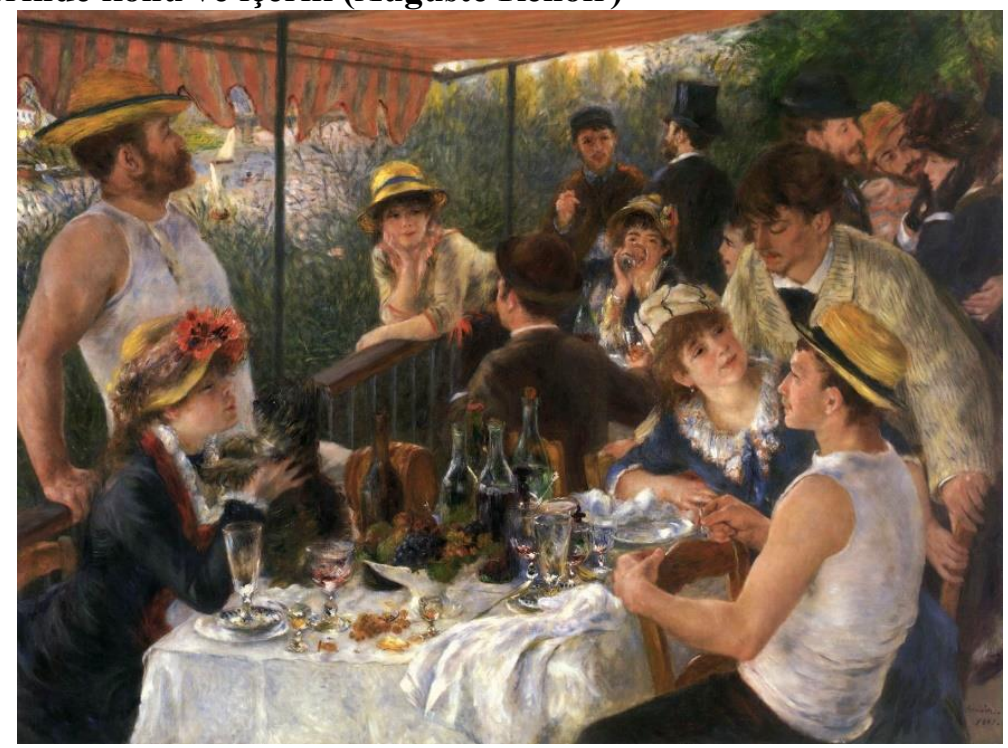

Resim-2: Pierre-Auguste Renoir'un "Sandalda Öğle Yemeği" / The Luncheon of the Boating party (1881), Tuval üzerine yağlı boya, $130 \times 173 \mathrm{~cm}$. The Phillips Collection, Washington, D.C.

Renoir'in "Sandalda Öğle Yemeği" adlı üstteki resmi oldukça karmaşı bir kompozisyona sahiptir. Bununla birlikte, hemen her figürün hareketi dikkatli bir biçimde belirlenmiştir (Newall, 2008, s. 87). Renoir'in "Tekne gezisinde öğle yemeği" adıyla da anılan bu ünlü tablosunda kucağında küçük bir köpeği tutan kadın; karısı Aline'dir (Pierre Auguste Renoir Biyografisi, t.y.). Bu nedenle resimlenen sahnenin az önce içinde ressam Renoir'un da olduğunu tahmin edebiliriz. O dönem Fransız ailelerin hafta sonlarını mesire yerlerinde geçirmesi revaçta olan bir etkinlikti. Newall $(2008$, s. 87$)$ bu duruma işaret ederek, Renoir'in bu resimde bir tür aylaklık sahnesinin atmosferini yakaladığını belirtmekte, resimde görülen sahnede figürler arasındaki yakın ilişkiler yerine atmosferin geneline odaklanıldığına dikkat çekmektedir (Newall, 2008, s. 87). Empresyonist ressamların resimde ayrıntıdan çok resmin genelini dikkate almasındaki en önemli faktörün gün ışığının yakalanması olduğunu söyleyebiliriz. Newall, resimde eskizimsi stilden söz ederek bu noktayı vurguluyor: Bununla birlikte, resmin merkezinde yer alan masa, izleyicinin bakışlarını figürlere yönelmesi görevini üstlenmiş durumdadır. Renoir resimdeki detayları vurgulamak için canlı renkler kullanmıştır. Kırmızı 1şık dokunuşlarıyla krem renkleri ve maviler resmin sağdan sola diyagonal kompozisyonu boyunca figürlerle bağlant1 kurmuştur (Newall, 2008, s. 89-90). Renoir'in resimde kurduğu kompozisyonda figürlerin kıyafetleri ve hareketlerini resmin tümüne yaydığı görülmektedir. Dağınık figürsel kompozisyon, Renoir'in espas derinliğini de dikkate alan kurgusuyla öne çıkmıştır. Dönemin özellikleri dikkate alındığında, bir fotoğraf makinesinin an'1 yakalama becerisine benzer biçimde, görsel bir temaşanın doyuruculuğunun resmin tamamına hâkim olduğu söylenebilir.

\section{D- Sanatçının tekniği (tarz-üslup) (Auguste Renoir)}

Önde gelen Empresyonist ressamlar arasında Claude Monet'in suyu vurgulamaya yatkın olmasına karşın, Renoir resimlerinde insanlar ve kıyafetlerine odaklanır (Newall, 2008, 9). Renoir, Monet'in 1şı̆̆ kullanma biçiminden etkilenmiştir ancak, Monet gibi doğa resimleri değil insan betimlemelerine odaklanmıştır (Pierre Auguste Renoir Kimdir?, t.y.). Empresyonistler resimde temsil açısından yeni formlar geliştirerek, modern konuları yeni stil ve tekniklerle yansıtmaya meylettiler. Bu nedenle, Claude Monet, Pierre-Auguste Renoir, Edgar Degas ve Camille Pissaro farklı üslup ve ilgileriyle gerçekleştirdikleri çalışmalarda akımın başat konu ve formlarının izi resimlerinde çokça görülür (Newall, 2008, s. 6-7). Bununla birlikte, "Sandalda Öğle Yemeği" adlı eserde klasik resmin izlerinin de figürsel gruplandırmalar açısından görüldüğü söylenebilir. Bu eserdeki figür betimlemelerinin hemen hemen hepsi 2'li veya 3'lü gruplardan oluşması, Lonardo da Vinci'nin "Son akşam yemeği”" adlı eserindeki figür gruplandırmalarını çağrıştırdığı ileri sürülebilir. Her ne kadar Renoir "Sandalda Öğle Yemeği”" adlı bu eserde dağınık kompozisyonu tercih etse de resimdeki figürleri kendi aralarında belli bir gruplandırmaya tabi tutarak, klasik dönem resim özelliklerinin tamamını reddetmediği söylenebilir. Renoir yaşamı boyunca geçirdiği "romatoid artrit" hastalığına rağmen, benimsediği stiller 
arasındaki geçiş (Empresyonist, Kuru ve İnci dönemleri) ve resim yapma tarzındaki coşkunluğun hastalığından olumsuz bir şekilde etkilenmeden gerçekleştirdiğini söyleyebiliriz (da Mota ve diğ., 2012). Renoir'in bu yaklaşım ve çabasını büyük bir sanatçı olarak yaptığı işe sayg1 ve tutkuyla bağlılığından ödün vermemesine bağlayabiliriz.

İlgili ders konusunu anlama ve anlamlandırma için açık uçlu değerlendirme soruları:

- Renoir'in uzlaşmacı kişiliğinin resmine yansıdığını düşünüyor musunuz?

- Renoir'in uzlaşmacı kişiliğinin resmine yansıdığını düşünüyorsanız, bunu açıklayabilir misiniz?

- Renoir 'in uzlaşmacı kişiliğinin resmine yansımadığını düşünüyorsanız, bunu açılayabilir misiniz?

- Renoir ile Monet'nin resimlerine baktığınızda konu açısından belirgin fark size göre nedir?

- Renoir ile Monet'nin resimlerine baktığınızda teknik açısından belirgin fark size göre nedir?

- Renoir ile Monet'nin resimlerine baktığınızda konu açısından belirgin benzerlik size göre nedir?

- Renoir ile Monet'nin resimlerine baktığınızda teknik açısından belirgin benzerlik size göre nedir?

- Renoir ve Monet'nin resimlerinde size göre öne çıkan formlar nelerdir?

- Renoir ve Monet'nin resimlerinin klasik resimlerden farklı olan noktalar nelerdir?

- Empresyonizm ve Empresyonist ressamlar hakkındaki görüşleriniz nelerdir?

- Empresyonist ressamların yaşadıkları çağı resimlerinde yansıttıklarını düşünüyor musunuz?

- Empresyonizm Akımının resim sanatına kattığı değer hakkında ne düşünüyorsunuz?

Sonuç olarak, tarihsel süreçte resim sanatı bilinirliğini, dönemini yansıtması açısından sanat akımları yoluyla sürdürmektedir. Dolayısıyla, resim sanatını yeni kuşaklara daha iyi aktarmada, genelde sanat eğitiminde, özelde resim akımlarında yeni öğretim yaklaşımlarının denenmesine ihtiyaç vardır. $\mathrm{Bu}$ araştırma, resim akımları konusunda uygulanabilecek bütüncül bir öğretim yaklaşım önerisi geliştirerek, ilgili alana önemli bir katk1 yapmıştır. İlerde yapılacak araştırmalar için, resim iş eğitiminde yeni öğretim yaklaşımlarının denenerek, faklı değişkenler açısından incelenmesi önerilir. Ayrıca, bu çalışmanın sonuçlarından yola çıkarak, mevcut ders konusunun işlenişi hakkında ilgili alanda olgusal bir araştırma yapılması önerilir.

\section{Kaynakça}

Artun, A. (2010). Sanat manifestoları. (1. Baskı). İstanbul: İletişim yayınları.

Bahadır, O. (2017). Bilimin büyük sosyal sonuçları. https://sarkac.org/2017/06/bilimin-buyuk-sosyalsonuclari// adresinden 28.06.2020 tarihinde alınmıştır.

Barrett, T. (2012). Sanatı eleştirmek. (G. Metin, Çev.). İstanbul: Hayalperest Yayınevi.

Bell, J. (2009). Sanatın yeni tarihi. (U. Ceren Ünlü, N. İleri, R. Gürtuna Çev.). İstanbul: NTV Yayınlar1.

Berger, J. (2005). Görme Biçimleri (Y. Salman, Çev.). İstanbul: Metis Yayınları.

Beyreli, L. ve Sönmez, H. (2017). Bloom taksonomisi ve yenilenmiş Bloom taksonomisi ile ilgili Türkiye'de yapılan çalışmaların odaklandığı araştırma konuları. International Journal of Languages' Education and Teaching, 5(2). 213-229. DOI: 10.18298/ijlet.1738

Bloom's taxonomy (t.y.). https://en.wikipedia.org/wiki/Bloom's_taxonomy adresinden 28.06.2020 tarihinde alınmıştır.

Claude Monet (2020). https://tr.wikipedia.org/wiki/Claude_Monet adresinden 29.06.2020 tarihinde alınmıştır.

Claude Monet Hayatı (t.y.). https://www.ressamlar.gen.tr/claude-monet-kimdir-hayati-biyografisi/ adresinden 29.06.2020 tarihinde alınmıştır.

Claude M. (2020). https://www.pivada.com/claude-monet adresinden 29.06.2020 tarihinde alınmıştır.

Claude Monet Biography (2019). https://www.biography.com/artist/claude-monet adresinden 29.06.2020 tarihinde alınmıştır.

da Mota, L.M.H., Neubarth, F., Diniz, L.R., de Carvalho, J. F. \& Dos Santos Neto, L. L. (2012). Pierre-Auguste Renoir (1841-1919) and rheumatoid arthritis. Journal of Medical Biography, 20(2).91-92. DOI:10.1258/jmb.2011.011028

Erem, E. (2009). Yaratıcı Drama Yöntemiyle Sanat Eğitiminde Sanat Akımları Öğretimine Yönelik Örnek Bir Çalı̧̧ma - Barok, İzlenimcilik, Dlşavurumculuk, Sürrealizm ve Romantizm. XVIII. Ulusal Eğitim Bilimleri Kurultayı. İzmir 1-3 Ekim. Türkiye.

Gombrich, E. H. (1992). Sanat ve yanılsama (A. Cemal, Çev.). İstanbul: Remzi Kitapevi. 
Gombrich, E. H. (2004). Sanatın öyküsü. (E. Erduran, Ö. Erduran, Çev.) (4.Bask1). İstanbul: Remzi Kitabevi.

Gözlükaya Işık, S. (2014). Resim-İş öğretmenliği sanat atölye derslerinde aktif öğrenme tekniklerinin sanatsal öğrenmeye katkısı. (Yayınlanmamış Yüksek Lisans tezi). Pamukkale Üniversitesi Eğitim Bilimleri Enstitüsü. Denizli.

Güzel, $\quad \dot{\text { İ. }}$ (2012). Fotoğraf makinesi'nin tarihçesi. https://sites.google.com/site/ismailguzel2012/home/fotograf-makinesi-nin-ta adresinden 28.06.2020 tarihinde alınmıştır.

Güneş, N. (2015). Çok alanlı sanat eğitimi yönteminin çağdaş sanat dersi öğretiminde kullanılmasının kalıcılığa etkisi. Tarihin Peşinde -Uluslararası Tarih ve Sosyal Araştırmalar Dergisi- Sayı 13, 3 Sayfa: 365-380. http://www.tarihinpesinde.com/dergimiz/sayi13/M13_14.pdf adresinden 26.06.2020 tarihinde alınmıștır.

Güneş, T. ve Öner, Z. (2017). Bağlam temelli öğrenme yaklaşımının öğrencilerin çevreye yönelik tutumlarına etkisi. International Journal of Social Sciences and Education Research, 3(1), 345-355. DOI:10.24289/ijsser.270661

Hollingswort, M. (2009). Dünya sanat tarihi. (R. Küçükerdoğan, Çev. 1-29. Blm., B. Ergüder, Çev. 30-52. Blm.). İstanbul: İnkîlap Kitabevi

İ̧̧erik Analizi Nedir? Nasıl Yapılır? (2017). https://www.icerik.net/icerik-analizi-nedir-nasil-yapilir adresinden 30.06.2020 tarihinde alınmıştır.

Kandinsky, V. (2015). Sanatta Ruhsallık Üzerine. (G. Ekici, Çev.). İstanbul: Çınar Matbaacılık.

Karadağ, A. (t.y.) Araştırma yöntem ve teknikleri. https://cdn.bartin.edu.tr/molekuler/688639be4387414caed98218fa08e666/arastirmayontemvet eknikleridersi.pdf adresinden 30.06.2020 tarihinde alınmıştır.

Kıral, B. (2020). Nitel bir veri analizi yöntemi olarak doküman analizi. Sosyal Bilimler Enstitüsü Dergisi (SUSBID), Sayı: 15, 170-189. https://dergipark.org.tr/tr/download/article-file/1156348 adresinden 04.06.2021 tarihinde alınmıştır.

Koçak, A. ve Arun, Ö. (2006). İçerik analizi çalışmalarında örneklem sorunu. Selçuk İletişim, 4(3), 21 28. https://dergipark.org.tr/tr/download/article-file/177956 adresinden 30.06.2020 tarihinde alınmıştır.

Kurtuluş, Y. (2001). Sanat eğitiminde işbirlikli öğrenme. Hacettepe Üniversitesi Eğitim Fakültesi Dergisi, 20: 201-205. http://www.efdergi.hacettepe.edu.tr/yonetim/icerik/makaleler/1007published.pdf adresinden 26.06.2020 tarihinde alınmıştır.

Literature Review (2020). https://guides.library.bloomu.edu/litreview adresinden 30.06.2020 tarihinde alınmıştır.

McCombes, S. (2020). Developing strong research questions. https://www.scribbr.com/researchprocess/research-questions/ adresinden 30.06.2020 tarihinde alınmıştır.

MEB Güzel Sanatlar Lisesi ögretim programı (2016). Çağdaş Dünya Sanatı Tarihi Dersi Öğretim Program1. http://mufredat.meb.gov.tr/Dosyalar/2019925184015643$\% \mathrm{C} 3 \% 87 \mathrm{a} \% \mathrm{C} 4 \% 9 \mathrm{Fda} \% \mathrm{C} 5 \% 9 \mathrm{~F} \% 20 \mathrm{~d} \% \mathrm{C} 3 \% \mathrm{BCnya} \% 20$ sanat\%C4\%B1\%20tarihi.pdf adresinden 26.06.2020 tarihinde alınmıştır.

MEB Görsel Sanatlar Dersi $(9,10,11$ ve 12 Sinıflar) öğretim programı (2018). http://mufredat.meb.gov.tr/Dosyalar/2018120204014821gorsel\%20sanatlar\%20dop\%20(2).pdf adresinden 26.06.2020 tarihinde alınmıştır.

Newall, D. (2008). Empresyonistler. (E. Dastarlı, N. Avan Özdemir, Çev.). İstanbul: Türkiye İş Bankası Yayınları.

Ormond, B. (2011). Transformative shifts in art history teaching: the impact of standards-based assessment, The Curriculum Journal, 22(4), 567-590. DOI:10.1080/09585176.2011.627225

Phillips, S. (2016). İzmler; Modern sanatı anlamak. (D. N. Özer, Çev.). İstanbul: Yem Yayın

Pierre Auguste Renoir Kimdir? (t.y.). http://www.kimkimdir.net.tr/kisiler/pierre-auguste-renoir adresinden 29.06.2020 tarihinde alınmıştır.

Pierre Auguste Renoir Hayatı (t.y.). https://www.ressamlar.gen.tr/pierre-auguste-renoir-kimdir-hayatibiyografisi/ adresinden 29.06.2020 tarihinde alınmıştır.

Pierre Auguste Renoir (2020). https://tr.wikipedia.org/wiki/Pierre_Auguste_Renoir adresinden 29.06.2020 tarihinde alınmıştır. 
Pierre Auguste Renoir Biyografisi (t.y.) https://www.biyografi.info/kisi/pierre-auguste-renoir adresinden 29.06.2020 tarihinde alınmıştır.

Pişkin, S. (2018). Claude Monet kimdir? https://birsanatbirkitap.com/sanat/sanat-tarihi/claude-monetkimdir/ adresinden 29.06.2020 tarihinde alınmıştır.

Resim-

https://www.yok.gov.tr/Documents/Kurumsal/egitim_ogretim_dairesi/Yeni-Ogretmen-

Yetistirme-Lisans-Programlari/Resim_Is_Ogretmenligi_Lisans_Programi09042019.pdf adresinden 27.06.2020 tarihinde alınmıştır.

San, İ. (2004). Sanat ve eğitim (3.Bask1). Ankara: Ütopya Yayınevi

What is a literature review? (2020). https://www.rlf.org.uk/resources/what-is-a-literature-review/ adresinden 04.07.2020 tarihinde alınmıştır.

Yarımca, Ö. (2010). İlköğretim II. kademe görsel sanatlar dersinde disiplinler arası yaklaşıma dayalı uygulamalar. (Yayınlanmamış Doktora tezi) Selçuk Üniversitesi Eğitim Bilimleri Enstitüsü. Konya.

\section{Resim Kaynakça}

Resim 1. Claude Monet, "İzlenim" / Impression, Sunrise. (1873). Tuval üzerine yağlıboya, 48 x 63 $\mathrm{cm}$. Musée Marmottan Monet, Paris. https://www.wga.hu/index1.html adresinden 28.06.2020 tarihinde alınmıştır.

Resim 2. Pierre-Auguste Renoir'un "Sandalda Öğle Yemeği” / The Luncheon of the Boating party (1881), Tuval üzerine yağlı boya, $130 \times 173 \mathrm{~cm}$. The Phillips Collection, Washington, D.C. https://www.wga.hu/index1.html adresinden 28.06.2020 tarihinde alınmıştır.

\section{Extended Abstract}

\section{Introduction}

In the art movements in general, the artists make the artwork by their technical and intellectual aspects within features of being era to reflect the object into the canvas. Therefore, the paint technique used by the artist in the artwork can also be one of the essential indicators to reflect the related era. Similarly, the compositional setup or the figural approach in the work can give us important clues about the period of the painting. In addition, it is necessary to take into account the dominant intellectual aspect of the period in the art movements. Therefore, the personality of the artist, information about his painting style, important developments in terms of science and society of the period need to be consider. Therefore, we can say that learning and assessing the art movements are possible depending on the period in which they emerged, the artist, socio-cultural, economic structure, and scientifictechnological developments. In addition, we can consider the chronological treatment of the art movements in terms of history as another important factor that will help us understand the art of painting. When we approach the subject from this perspective, there is a need for a versatile perspective in understanding and interpreting the art movements. In contrast, it is difficult to argue that the subject of the art movements, which covers in the visual art education curriculum as a unit title or a sub-title of the course, exhibits a holistic structure. That is, the course contents just simply appear as a structure associated with the dominant artist or work of the art movement. The art movements should be learned from a broad perspective in terms of students' understanding because the art movements and the artwork concern very complex and multifaceted structures. In this way, the subject of the art movements is difficult to say the course outcome supports the student's interpretation sufficiently in terms of the art. In this point, there is a need for a multifaceted-holistic learning approach developed with a versatile perspective in a chronological context. The purpose of this research is to suggest the multifaceted and holistic learning approach to the field of art education that will help students' understanding and make sense of the art movements. Accordingly, research question was determined as follows: "Could a multifaceted-holistic learning approach be developed for the student to understand and make sense of the art movements?" 


\section{Method}

This research used document analysis technique as based on the literature review. The documents under the research problem, obtained from the literature review. In Document Analysis, the researcher determines the suitability of the documents for the research problem. Therefore, the researcher examines and evaluates the documents. In this way; as a related subject, knowledge development is possible as the relevant subject by interpreting the data.

\section{Results}

The subject of the art movements, which is included as a subtitle in the "History of Contemporary World Art" course in the visual arts education in terms of high school curriculum of the Ministry of National Education (M.E.B.) involves understanding, whereas it seems that there is no place for the meaning in terms of the purposes of the lesson. On the other hand, the contents of the "History of Western Art" and "Contemporary Art" courses in the visual arts education Undergraduate Program in the higher education are the continuation of each other; they take place in different education levels. Therefore, these lessons present a fragmented structure regarding the art movements. Accordingly, we can say that related lessons do not contain a holistic learning approach in terms of the art movements at the higher education level to make sense of students' art movements within the program's framework. As a result, there is a need more holistic learning approach than present for the student to understand and make sense of the artwork subject including the conditions of the period and scientific - technological developments in the art movement. Therefore, the researcher invented a Holistic learning Wheel as Diagram-1 in Visual Arts Education. Suppose the teacher considers the Holistic Learning Wheel; in that case, the students can easily understand and make sense of the art movements in the learning process, benefiting the multifaceted-holistic learning approach. Consequently, this study suggested a holistic learning approach for the students in the art movement subject that covers the characteristics of the period, the artist's personality, technique, subject and content. 